\title{
Study on Biodegradation of Mechanic Workshop Polluted Soil Amended with Lime Fertilizer
}

\author{
Stephen Emmanuel ${ }^{1}$, Okwute Loretta Ojonoma ${ }^{2}$, Idoko Peter Arome ${ }^{1}$, Makolo Daniel ${ }^{3}$ \\ ${ }^{1}$ Department of Microbiology, Kogi State University, Anyigba-Kogi State, Nigeria \\ ${ }^{2}$ Department of Microbiology, University of Abuja, Gwagwalada- Abuja, Nigeria \\ ${ }^{3}$ School of Preliminary Studies, Kogi State Polytechnic, Kogi State, Nigeria \\ Email address: \\ psychsea07@gmail.com (S. Emmanuel)
}

\section{To cite this article:}

Stephen Emmanuel, Okwute Loretta Ojonoma, Idoko Peter Arome, Makolo Daniel. Study on Biodegradation of Mechanic Workshop Polluted Soil Amended with Lime Fertilizer. International Journal of Environmental Monitoring and Analysis.

Vol. 4, No. 1, 2016, pp. 21-26. doi: 10.11648/j.ijema.20160401.14

\begin{abstract}
Biodegradation of mechanic workshop polluted soil amended with $2.4 \mathrm{~kg}$ lime (Confluence fertilizer) was studied for a period of eight weeks (56 days). This was done by physicochemical analysis of the soil samples and microbiological analysis by spread plate inoculation on Nutrient agar (NA). The results revealed higher bacteria population in amended soil (AS) compared to oil free soil (OFS) and polluted soil (PS). The range of bacterial counts was Oil free soil $\left(1.6 \times 10^{4}-6.8 \times 10^{4}\right.$ $\mathrm{cfu} / \mathrm{g})$, polluted soil $\left(2.2 \times 10^{4}-9.8 \times 10^{4} \mathrm{cfu} / \mathrm{g}\right)$ and Amended soil $\left(1.62 \times 10^{4}-1.12 \times 10^{5} \mathrm{cfu} / \mathrm{g}\right)$. The fungi counts range were Oil free soil $\left(2.5 \times 10^{3}-3.0 \times 10^{4} \mathrm{cfu} / \mathrm{g}\right)$, polluted soil $\left(2.2 \times 10^{3}-4.0 \times 10^{4} \mathrm{cfu} / \mathrm{g}\right)$ and Amended soil $\left(2.1 \times 10^{3}-2.7 \times 10^{3} \mathrm{cfu} / \mathrm{g}\right)$. Eleven (11) organisms were isolated in the course of this study. The bacteria isolated were Pseudomonas putida, Bacillus subtilis, Micrococcus luteus, Proteus mirabilis and Staphylococcus aureus while the fungi isolated include Mucor mucedo, Candida tropicalis, Aspergillus niger, Aspergillus flavus, Aspergillus fumigatus and Rhizopus nigricans. The moisture content (MC), organic carbon, organic matter, $\mathrm{pH}$ and nitrate were higher in amended soil compared to unpolluted soil and polluted soil. The result of the study shows that lime (confluence fertilizer) can be used to enhanced biodegradation of oil polluted soil.
\end{abstract}

Keywords: Lime, Polluted Soil, Biodegradation, Inoculation

\section{Introduction}

Ismail [1] defined biodegradation as biological activities resulting in the breakdown of a compound or organic contaminant. The use of these biological activities is low-cost and a sustainable remediation method for contaminated soil [2]. Use of living organisms such as bacteria for degradation of hydrocarbons in the environment is connected to a number of physical and chemical factors including the concentration and chemical structure of contaminant, moisture, oxygen, temperature and $\mathrm{pH}[3]$.

Anene and Chika [4] reported that the rate and efficiency of biodegradation depend on the occurrence of adequately numerous and active microflora in the contaminated or polluted environment. Biodegradation of complex molecules usually involves the interactive effect of mixed populations of micro-organisms and relies on the metabolic versatility of bacteria and fungi and the rate of degradation depends on the composition of the molecules [5].
Biodegradation of petroleum hydrocarbons is a complex process that depends on the nature and the number of hydrocarbons. Different factors influencing hydrocarbon degradation have been reported by [6]. One of the important factors that limit biodegradation of oil pollutants in the environment is their limited availability to microorganisms. Petroleum hydrocarbon compounds bind to soil components and they are difficult to be removed or degraded [7]. Hydrocarbons differ in their susceptibility to microbial attack.

Bacteria are the most active agents in petroleum degradation and they work as primary degraders of spilled oil in the environment $[8,9]$. Several bacteria are even known to feed exclusively on hydrocarbons [10]. Acinetobacter species was found to be capable of utilizing n- alkanes of chain length $\mathrm{C}_{10}-\mathrm{C}_{40}$ as a sole source of carbon [11]. Bacterial genera namely, Gordonia, Mycobacterium, Brevibacterium, Aeromicrobium, Dietzia, and Burkholderia isolated from petroleum contaminated soil proved to be the potential organisms for hydrocarbon degradation [12]. 
According to Stephen et al. [2], microorganisms such as Pseudomonas sp., Acinetobacter spp, Flavobacterium spp, Micrococcus spp, Bacillus spp, Candida spp, Aspergillus spp, Rhizopus spp, Alcaligenes and Trichoderma spp have the potential to degrade hydrocarbons.

Singh [13] reported a group of terrestrial fungi, namely, Aspergillus, Cephalosporium and Pencillium which were found to be potential degraders of crude oil. The Candida tropicalis species namely, Candida lipolytica, Rhodotorula mucilaginosa, Geotrichum sp, and Trichosporon mucoides isolated from contaminated water were also noted to degrade petroleum compound [14].

In mechanic workshops, there are accidental or deliberate releases or discharge of petrol, diesel, solvents, grease and lubricants on the land. Many of these petroleum products are organic chemicals that can be highly toxic and hazardous to soil fauna and man. The use of automobiles has also led to increase in trace elements and heavy metal contamination in the environment [15]. Contamination of soil environment by hydrocarbons (mostly petroleum hydrocarbons) is becoming prevalent across the globe. This is probably due to heavy dependence on petroleum as a major source of energy throughout the world, rapid industrialization, population growth and complete disregard for the environmental health [16].

Petroleum products such as lubricating oil, petrol, and diesel are used in various forms in mechanic workshops. These products tend to harden and change the colour of the soil. It may also have adverse effect on the soil microbiota as well as the physicochemical properties such as $\mathrm{pH}$ of the soil [3] and create an imbalance in the Carbon-Nitrogen $(\mathrm{C} / \mathrm{N})$ ratio at the spill site (mechanic workshop). This may result in nitrogen deficiency in an oil-soaked soil which retards the growth of bacteria and the utilization of carbon sources [17]. Furthermore, a large amount of biodegradable organics in the top layers of soils depletes oxygen reserves in the soil and slows down the rate of oxygen diffusion to the deeper layer [17].

\section{Related Work}

Bioremediation is considered to be a more economical and safe method for the treatment of oil contaminated sites. According to [18] bioremediation is an alternative to conventional methods such as use of chemicals in reclaiming oil polluted sites by the addition of specific microorganisms (bacteria, cyanobacteria, algae and fungi) or enhancement of metabolic activities of micro-organisms already present in polluted soil.

Liming is the use of calcium and magnesium to enrich soil by the addition of different substances such as limestone, hydrated lime, and chalk. These substances help neutralize the soil acidity and improve the soil activity suitable for microorganisms [19]. Soil $\mathrm{pH}$ is affected by several factors such as decomposition of organic matter, precipitation, native vegetation, nitrogen fertilization and flooding. Lime reduces soil acidity with respect to $\mathrm{Ca}^{2+}$ ion and lime replaces two $\mathrm{H}^{+}$ ions on the cations exchange complex. The lime dissolves to form calcium, bicarbonate, and hydroxide ions. The hydroxide neutralizes soil acidity by combining with hydrogen ions to form water [20].

Oil polluted soil is acidic and the oil alters microbiological and physicochemical properties of the soil negatively and it also affects soil fertility. If polluted soil is not amended, it will be unproductive for long period of time and consequently, affect agricultural productivity. Mechanic workshop soil cannot be put to agricultural use unless it is reclaimed. The aim of this study is to reclaim mechanic workshop soil polluted with petroleum product (diesel, petrol, lubricating oil etc.) using lime fertilizer which is readily available in Anyigba as a result of the Confluence Lime Fertilizer Company in Anyigba, Kogi State.

\section{Materials and Methods}

\subsection{Study Area}

Anyigba is located in Dekina Local Government Area (L.G.A) of Kogi State, Nigeria. It has a total population of 130,000 [21]. It has many automechanic workshops and it is heavily patronized especially in the area of automobile body works, spraying and engine fitting. All the sites have typical characteristics of automobile work sites such as patches of waste engine oil on the ground, discarded engine oil containers and paint cans.

\subsection{Sample Collection}

Soil sample was collected at surface depth of $0-10 \mathrm{~cm}$ from a mechanic workshop opposite Kogi State University, Anyigba. The soil is characterized by its hardened surfaces and blackish colour. Soil sample which served as control was also collected from unpolluted and hydrocarbon free soil behind Faculty of Natural Sciences Laboratory, Kogi State University, Anyigba. Nigeria.

\subsection{Experimental Design}

The soil samples were transferred into three perforated plastic pots. The pots were arranged in rows and labeled OFS, PS, and AS. The pot labeled OFS contained $8 \mathrm{~kg}$ $(8000 \mathrm{~g})$ of oil free soil which served as control, PS contained $8 \mathrm{~kg}(8000 \mathrm{~g})$ unamended mechanic workshop polluted soil and the third pot AS contained $8 \mathrm{~kg}(8000 \mathrm{~g})$ mechanic workshop polluted soil amended with $30 \%(2.4 \mathrm{~kg})$ lime fertilizer. The pots were perforated at the sides and bases to increase aeration and to avoid water logging. The soil samples were watered twice a week.

\subsection{Sample Analysis}

Sampling was conducted bi-weekly for a period of 56 days (8 weeks) to determine the microbiological components and physicochemical properties of the soil. Soil samples were taken from two different parts of each bowl and homogenised. The soil samples from the three pots were analyzed microbiologically using serially diluted 1 gram measurements 
and spread plate inoculated on Nutrient agar (NA) as described by [22]. $\mathrm{pH}$ was determined as described by [23] in $1: 1$ water to soil ratio. Nitrate was determined by the micro Kjedahl method [24]. The phosphorus content and moisture were determined using the Survey Laboratory [25] method. The ignition method [26] was used to determine the organic matter content. Descriptive statistics and analysis of variance (ANOVA) was performed using SPSS version 16. Experimental precision achieved was reported at $\mathrm{p} \leq 0.05$ level.

\section{Results}

Figure 1 shows the total bacteria counts in the oil free soil (OFS), polluted soil (PS), and amended soil (AS). Higher bacteria counts was observed in amended soil than OFS and PS. The bacteria counts ranged from $1.62 \times 10^{4}$ $1.12 \times 10^{5} \mathrm{cfu} / \mathrm{g}$ for $\mathrm{AS}, 1.6 \times 10^{4}-6.8 \times 10^{4} \mathrm{cfu} / \mathrm{g}$ for OFS. $2.2 \times 10^{4}-9.8 \times 10^{4} \mathrm{cfu} / \mathrm{g}$ for PS. The highest count $\left(1.12 \times 10^{5} \mathrm{cfu} / \mathrm{g}\right)$ was recorded at day 28 in amended soil while the lowest count $\left(1.6 \times 10^{4} \mathrm{cfu} / \mathrm{g}\right)$ was recorded in OFS at day 56.

Figure 2 shows the total fungi count in OFS, PS and AS. The fungi counts ranged from $2.1 \times 10^{3}-2.7 \times 10^{3} \mathrm{cfu} / \mathrm{g}$ for AS, $2.5 \times 10^{3}-3.0 \times 10^{4} \mathrm{cfu} / \mathrm{g}$ for OFS and $2.2 \times 10^{3}-4.0 \times 10^{4}$ $\mathrm{cfu} / \mathrm{g}$ for PS. The highest fungi count $\left(4.0 \times 10^{4} \mathrm{cfu} / \mathrm{g}\right)$ was observed at day 0 in PS while the lowest fungi count $\left(2.1 \times 10^{3} \mathrm{cfu} / \mathrm{g}\right)$ was observed in AS at day 14 and at day 42 .

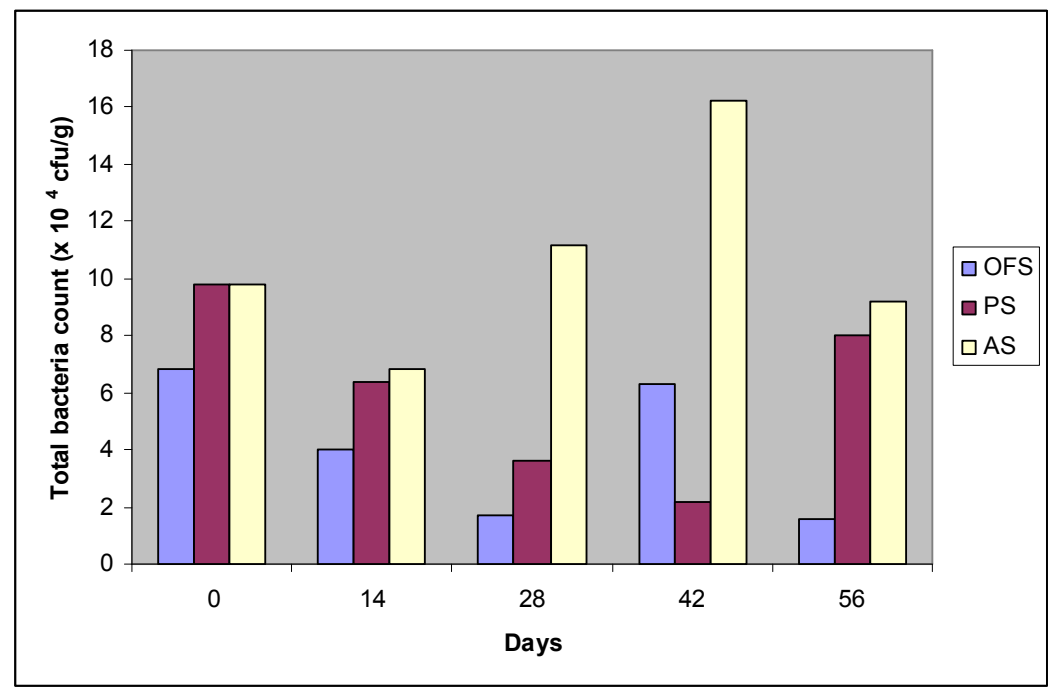

OFS: Oil free soil, PS: Polluted soil, AS: Amended soil

Fig. 1. Total bacteria count obtained from mechanic workshop soil amended with lime.

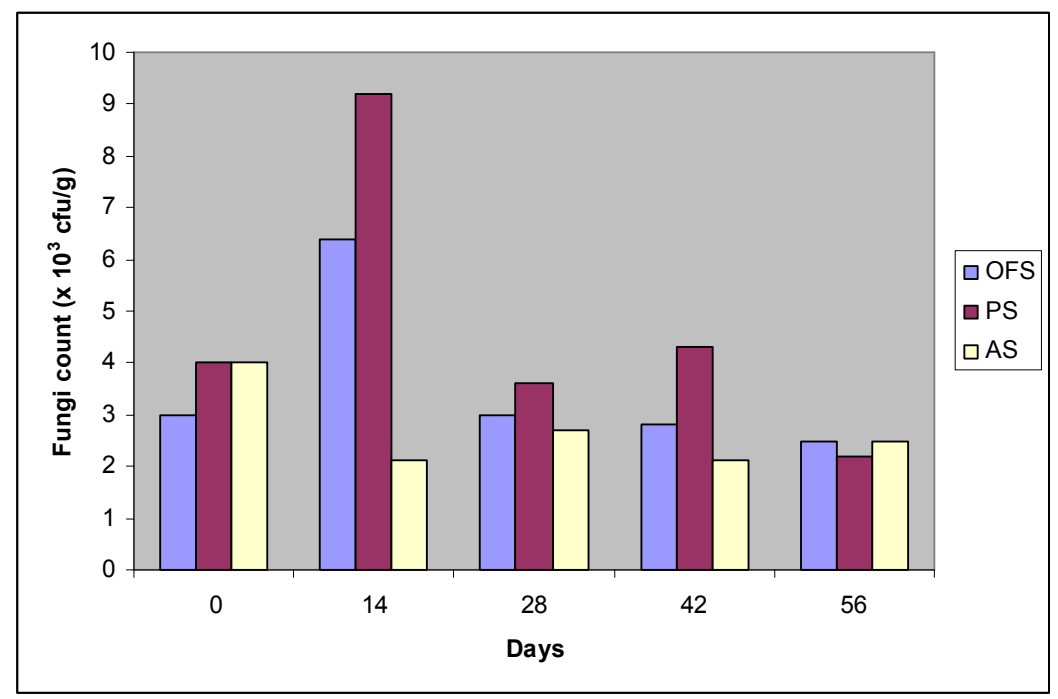

OFS: Oil free soil, PS: Polluted soil, AS: Amended soil

Fig. 2. Fungi count obtained from mechanic workshop soil amended with lime.

Table 1 shows the frequency and occurrence of bacteria and fungi isolates from OFS, PS and AS. Mucor spp had the highest frequency of occurrence with $22.41 \%$ followed by Bacillus subtilis with $18.97 \%$, Pseudomonas putida $10.34 \%$, 
Staphylococcus aureus and Aspergillus niger had 8.62\%, Proteus mirabilis, Rhizopus nigricans and Aspergillus fumigatus $6.90 \%$, Micrococcus luteus had $5.17 \%$, Aspergillus flavus $3.45 \%$ while Candida tropicalis had the least frequency with $1.72 \%$.

Table 2 shows the results of the physicochemical parameters of the soil samples. The $\mathrm{pH}$ in all samples were weakly acidic. It ranged from $6.22 \pm 0.22$ to $6.59 \pm 0.29$. There were no significant differences in the $\mathrm{pH}$ of the soil samples at $5 \%$ probability level.

The electrical conductivity was low in all samples. The highest electrical conductivity value was recorded in the amended soil, AS $(1.58 \pm 1.24 \mathrm{Ms} / \mathrm{cm})$ followed by the unamended polluted soil, PS $(0.49 \pm 0.07 \mathrm{Ms} / \mathrm{cm})$ while the least value was recorded in oil free soil, OFS $(0.46 \pm 0.11 \mathrm{Ms} / \mathrm{cm})$. There were no significant differences $(\mathrm{p}>0.05)$ between OFS, PS and PS.

The moisture content was relatively high in all treatments. The moisture content ranged from $6.55 \pm 2.00$ to $8.11 \pm 1.66 \%$. The least moisture content was observed in AS while the highest value was recorded in PS. There were no significant differences $(p>0.05)$ in the moisture contents between the treatments.

The organic matter content and organic carbon increased linearly from OFS to AS. In both parameters, the highest values were recorded in AS followed by PS and OFS. The organic matter content ranged from $1.29 \pm 0.33-5.43 \pm 2.85 \%$. There was no significant difference in the organic matter content at $5 \%$ probability level. In the organic carbon, the values ranged from $0.75 \pm 0.13-1.84 \pm 0.45 \%$. Significant differences $(p \leq 0.05)$ exist in the organic carbon between OFS, PS and AS.

Nitrate content was low in all treatments. The nitrate content ranged from $0.09 \pm 0.02-0.60 \pm 0.32 \%$. There was no significant difference in the nitrate content of the soil samples at $5 \%$ probability level.

The level of phosphorus in the soil samples was high in all treatments. The phosphorus ranged from $6.97 \pm 1.65$ $10.39 \pm 2.24 \%$. There was no significant difference in the nitrate content of the soil samples at $5 \%$ probability level.

Table 1. Frequency and Occurrence of Isolates obtained from mechanic workshop soil undergoing bioremediation.

\begin{tabular}{llllll}
\hline Organisms & OFS & PS & AS & Total & \% Total \\
\hline Bacillus subtilis & 5 & 4 & 2 & 11 & 18.97 \\
Pseudomonas putida & 1 & 2 & 3 & 6 & 10.34 \\
Staphylococcus aureus & 1 & 1 & 3 & 5 & 8.62 \\
Proteus mirabilis & - & 3 & 1 & 4 & 6.90 \\
Micrococcus luteus & 1 & 1 & 1 & 3 & 5.17 \\
Rhizopus nigricans & 1 & 2 & 1 & 4 & 6.90 \\
Aspergillus niger & 2 & 1 & 2 & 5 & 8.62 \\
Aspergillus flavus & 1 & - & 1 & 2 & 3.45 \\
Aspergillus fumigatus & - & 2 & 2 & 4 & 6.90 \\
Mucor mucedo & 5 & 4 & 4 & 13 & 22.41 \\
Candida tropicalis & - & 1 & - & 1 & 1.72 \\
Total & 17 & 21 & 20 & 58 & 100 \\
\hline
\end{tabular}

OFS: Unpolluted soil, PS: Mechanic workshop soil, AS: Mechanic workshop soil Amended.
Table 2. Physicochemical qualities of mechanic workshop polluted soil $(M+S E)$.

\begin{tabular}{llll}
\hline Parameter & OFS & PS & AS \\
\hline $\mathrm{pH}$ & $6.49 \pm 0.27^{\mathrm{a}}$ & $6.22 \pm 0.22^{\mathrm{a}}$ & $6.65 \pm 0.29^{\mathrm{a}}$ \\
$\mathrm{EC}(\mathrm{Ms} / \mathrm{cm})$ & $0.46 \pm 0.11^{\mathrm{a}}$ & $0.49 \pm 0.07^{\mathrm{a}}$ & $1.58 \pm 1.24^{\mathrm{a}}$ \\
Moisture (\%) & $7.36 \pm 3.05^{\mathrm{a}}$ & $8.11 \pm 1.66^{\mathrm{a}}$ & $6.55 \pm 2.00^{\mathrm{a}}$ \\
Organic matter (\%) & $1.29 \pm 0.23^{\mathrm{a}}$ & $3.60 \pm 0.78^{\mathrm{a}}$ & $5.45 \pm 0.79^{\mathrm{a}}$ \\
Organic carbon (\%) & $0.75 \pm 0.19^{\mathrm{b}}$ & $1.04 \pm 0.42^{\mathrm{b}}$ & $1.84 \pm 0.45^{\mathrm{a}}$ \\
Nitrate (\%) & $0.09 \pm 0.02^{\mathrm{a}}$ & $0.20 \pm 0.03^{\mathrm{a}}$ & $0.60 \pm 0.32^{\mathrm{a}}$ \\
Phosphorus (\%) & $8.23 \pm 0.96^{\mathrm{a}}$ & $10.39 \pm 2.24^{\mathrm{a}}$ & $6.97 \pm 1.65^{\mathrm{a}}$ \\
\hline
\end{tabular}

a,b,c: means denoted by different superscripts along the same row are significantly $(\mathrm{p}<0.05)$ different. Values are mean of five replicates.

OFS: Unpolluted soil, PS: Polluted control soil, AS: Amended soil, EC: Electrical conductivity

\section{Discussion}

Higher bacteria and fungi counts were observed in amended soil (AS) compared to polluted soil (PS) and oil free soil (OFS). This could be due to the presence of high organic matter, moisture content, organic carbon and nitrate present in amended soil. This is in agreement with the findings of $[27,28,29]$. They reported increase in microbial population in contaminated soil undergoing bioremediation. The organisms isolated were Bacillus subtilis, Pseudomonas putida, Staphylococcus aureus, Micrococcus species, Proteus species, Candida tropicalis, Mucor species, Aspergillus niger, Aspergillus flavus and Aspergillus fumigatus. These organisms were reportedly isolated by other researchers [2, 28, 30].

Weakly acidic $\mathrm{pH}$ was observed in the soil samples. This could be attributed to active biodegradation process in the mechanic workshop polluted soil. The amended soil had a higher $\mathrm{pH}$ compared to the oil free soil and the polluted control soil (PS). This may be due to the addition of the lime fertilizer. The $\mathrm{pH}$ range observed in this study has been reported to favour biodegradation of hydrocarbon products [31].

Electrical conductivity was significantly higher in the amended soil compared to the polluted soil unamended soil and the oil free soil. This could be attributed to increased ions present in the amended soil as a result of the presence of lime fertilizer. The lime dissolves to form calcium, bicarbonate, and hydroxide ions. The hydroxide neutralizes soil acidity by combining with hydrogen ions to form water [20].

The moisture content was high in all the soil samples. This could be as a result of the oil in the mechanic workshop soil and insufficient aeration of the soil as a result of the displacement of air in the soil. This is in line with [32] who reported higher moisture content in crude oil contaminated soils.

The organic carbon and organic matter content were low in all soil samples. Carbon and organic matter are utilized by degrading bacteria and fungi for their growth. Carbon serves as source of nutrients and also required for metabolism by microbes. Stephen and Temola [31] reported similar results in spent lubricating oil polluted soil amended with poultry litter. 
Nitrate concentration was higher in amended soil (AS) than in polluted soil (PS) and oil free soil (OFS). The reason could be due to higher organic matter content observed in AS compared to PS and OFS. The nitrate level of AS in this study is higher than the report of [33].

The phosphorus concentration was higher in PS than in OFS and AS. This may be due to the inability of the microbes to immobilize it in the unamended soil compared to the amended soil where the addition of the lime might have improved the metabolism of the phosphorus in the mechanic workshop soil.

\section{Conclusion}

The results of this study showed that higher microbial counts were recorded in mechanic workshop amended soil (AS) than in unamended mechanic polluted soil (PS) and oil free soil (OFS). The nitrate, moisture content, organic carbon, organic matter, electrical conductivity and $\mathrm{pH}$ were also higher in the amended soil than those of unamended polluted soil (PS) and oil free soil. Hence, it is suggested that lime fertilizer can be used to amend soil polluted with petroleum products such as petrol, diesel and spent lubricating oil.

\section{References}

[1] Ismail, S. (2008). Bioremediation Laboratory Manual. Department of Biotechnology, Islamic University, Gaza, Israel, 8-15.

[2] Stephen, E., Emmanuel, O.E., Okpanachi, O.S., Emmanuel, S., Temola, O.T., Musa, K. and Ebiloma, I.P. (2013a). In-vitro study of biodegradation of spent lubricating oil by Aspergillus niger. Nature and Science, 11 (10): 40-44.

[3] Stephen, E., Job, O.S. and Abioye, O.P. (2013b). Study on biodegradation of Diesel contaminated soil amended with cowpea chaff. Journal of Science \& Multidisciplinary Research, 2(1):14-18.

[4] Anene, M. and Chika, N. (2006). Studies on the bioutililization of some petroleum hydrocarbons by single and mixed cultures of some bacterial species. African Journal of Microbiology Researchers, 5(12): 1457-1466.

[5] George, J.S. and Metting, Jr. (1993). Soil Microbial Ecology. Application in Agricultural Environmental Management. Mercel Dekker., Inc. New York.

[6] Cooney, J.J., Silver, S.A. and Beck, E.A. (1985). Factors influencing hydrocarbon egradation in three freshwater lakes, Microbial Ecology, 11(2): 127-137.

[7] Barathi, S. and Vasudevan, N. (2001). Utilization of petroleum hydrocarbons by pseudomonas fluorescens isolated from a petroleum-contaminated soil. Environmentalist, 26(5-6): 413 416.

[8] Rahman, K.S.M, Kourkoutas, Y., Petsas, I., Marchant. R. and Banat, I.M. (2003). Enhanced bioremediation of n-alkane in petroleum sludge using bacterial consortium amended with Rhamnolipid and Micronutrients. Bioresource Technology, 90 (20): $159-168$.
[9] Brooijmans, R.J.W., Pastink, M.I and Siezen, R.J. (2009). Hydrocarbon-degrading bacteria: The oil-spill cleanup crew, Microbial Biotechnology, 2(6): 587-594.

[10] Yakimov, M.M., Timmis, K.N. and Golyshin, P.N. (2007). Obligate oil-degrading marine bacteria. Current Opinions in Biotechnology, 18(3): 257-266.

[11] Throne-Holst, M., Wentzel, A., Ellingsten, T.E., Kotlar, H.K. and Zotcher, S. B. (2007). Identification of novel genes involved in long-chain n-alkane degradation by Acinetobacteria sp. Strain DSM 17874, Applied and Environmental Microbiology, 73 (10): 3327-3332.

[12] Chailan, F., Le Fleche, A., Bury, E., Phantavog, Y.H., Grimont, P., Saliot, A. and Oudot, J. (2004), Identification and biodegradation potential of tropical aerobic hydrocarbon degrading micro-organisms, Research in Microbiology. 15(7): 587-595.

[13] Singh, H. (2006). Mycoremediation: Fungal Bioremediation, Wiley-Interscience, New York, NY, USA.

[14] Boguslawska- was, E. and Dabrowski W. (2001). The seasonal variability of Candida tropicalis and Candida tropicalis- like organisms in water and bottom sediment of the Szczecin lagoon, International Journal of Hygiene and Environmental Health, 203(5-6): 451-458.

[15] Gupta, U.C. and Gupta, S.C. (1998).Trace Element Toxicity Relationship to Crop Production, Livestock and Human Health. Comm. Soil Science. Plant Anal. 29: 1491-1522.

[16] Lin, J. and Mandri, T. (2007). Isolation and Characterization of engine oil degrading Indigenous microorganisms in Kwazulu-Natal, African Journal of Biotechnology. 6(1): 2327.

[17] Akunne, I. (2007). Effects of Oil Spillage on Farm Land (A Case Study of Uroboh). Department of Agricultural and Bioresources Engineering, University of Nigeria, Nsukka, Nigeria.

[18] Hagwell, L.S., Delfino, L.M. and Rao, J.J. (1992). Partitioning of polycyclic aromatic hydrocarbon from oil into water, Environmental Science and Technology. 26(11): 2104- 2110.

[19] Chesworth, W. (2008). Encyclopedia of Soil Science. Springer The Netherlands.

[20] Moore, S. (2006). How does lime affect soil? http://homeguides. Sfgate.com/lime-affact-soil- 72806.html. Retrieved on the $5^{\text {th }}$ January, 2015.

[21] Omole, I.A. and Stephen, E. (2014). Antibiogram profile of bacteria isolated from wound infection of patients in three hospitals in Anyigba, Kogi State, Nigeria. FUTA Journal of Research in Sciences, 2: 258 - 266.

[22] Public Health England. (2014). Preparation of samples and dilutions, plating and sub-culture. Microbiology Services. Food, Water and Environmental Microbiology Standard Method FNES26 (F2). Version 1.

[23] Ibitoye, A.A. (2006). Laboratory Manual on Basic Soil Analysis (2nd ed). Foladave Nigeria Limited, Akure, pp 3037.

[24] Association of official Analytical Chemist. (AOAC, 2005). Methods of Analysis, Washington D.C. 
[25] Soil Survey Laboratory. (1996). Soil survey laboratory methods manual. Soil survey investigations report no. 42. Ver. 3.0. USDA-NRCS, Lincoln, NE.

[26] Akinsanmi O. (1975). Certificate Agricultural Science. Longman, Nigeria, 104-112.

[27] Okerentugba, P.O. and Ezeronye, O. U. (2003). Petroleum Degrading Potential of Single and Mixed Microbial Cultures Isolated From Rivers and Refinery Effluents in Nigeria. African Journal of Biotechnology, 2 (9): 288-292.

[28] Eze, V.C. and Okpokwasili, G.C. (2010). Microbial and other related changes in a Niger Delta River sediment receiving industrial effluents. Continental Journal of Microbiology, 4: 15 - 24 .

[29] Okwute, O.L. and Ijah, U.J.J. (2014). Bioremediation of Palm oil mill effluent (POME) polluted soil using microorganisms found in Organic Wastes. The International Journal of Biotechnology, 3 (3): 32-46.

[30] Atlas, R. M. and Cerniglia, C. E. (1995). Bioremediation of petroleum pollutants. Biological Science; 45(5): 332-350.

[31] Stephen, E. and Temola, O.T. (2014). Enhanced biodegradation of spent lubricating oil contaminated soil using poultry litter. British Biotechnology Journal 4(8):868-876.

[32] Osazee, E., Shehu, K. and Yerima, M.B. (2014). Physicochemical properties of oil contaminated soil as influenced by cow dung. Annals of Biological Sciences 2(4): $51-55$

[33] Mbah, C.N., Nwite, J.N., and Okporie, O.E. (2006). Effect of organic waste on some physicochemical properties and productivity of spent oil ultisol in Abakaliki, Nigeria. Nigerian Journal of Tropical Agriculture 8:51-56. 